\title{
Moral and Religious Learning Innovation through Information Technology (Descriptive Study at SD Muhammadiyah Manyar Gresik)
}

\author{
Ismail Marzuki ${ }^{1}$, Iqnatia Alfiansyah ${ }^{2}$, Arisona Dia Indah Sari ${ }^{3}$, Nanang \\ Khoirul Umam ${ }^{4}$
}

${ }^{1-4}$ Lecturer, Faculty of Teacher Training and Education, University of

Muhammadiyah Gresik 61121, Indonesia.

ismailmarzuki@umg.ac.id, iqnatia@umg.ac.id, arissona@umg.ac.id, nanang.khu@umg.ac.id

\begin{abstract}
The purpose of this study was to seek in-depth information about moral and religious learning innovations through information technology at SD Muhammadiyah Manyar. Through information technology learning planning, learning implementation, and learning evaluation will be easier, more practical, and faster. This type of research is descriptive research, the subject of research is the principal, vice principal in the field of curriculum, teachers, and the moral and religious learning process in schools. The research design: research planning $\rightarrow$ research implementation $\rightarrow$ research data analysis $\rightarrow$ drawing conclusions $\rightarrow$ making reports. Data collection techniques are through observation, interviews, and study of learning documents. All research data will be analyzed and the analysis model used is the Mils and Hubermen model. In this model, the analysis steps are: (1) data reduction, (2) data presentation, and (3) drawing conclusions / verification. There are three findings from the results of this study related to the use of IT in moral and religious learning at Muhammadiyah Elementary School Manyar: 1) in learning ethics, faith, and school worship utilizing learning videos, 2) utilizing video calls for the habit of praying for students at home, 3) use of murattal recordings to practice pronunciation and memorization of the Qur'an.
\end{abstract}

Keywords: Learning innovation, information technology

\section{Introduction}

The existence of information technology in learning today is very important. There are 5 reasons why information technology is important, including: 1) Information technology equipment is affordable and the price is getting cheaper over time. With the affordability of this device, it is not surprising that its users have become more and more widespread and it is almost certain that every school has it; 2) Through the world wide web (www) it will be easier for teachers to access and get learning information because any information is available there; 3) Information provided by search engines (browsers) can be obtained in various forms such as text, images, sound, and videos; 4) The internet today is a necessity because through the internet one can easily communicate with other people even in distant parts of the world; 5) The internet currently provides many free services and can be connected to a computer which makes it easier for every user [1] [2].

So far, research on information technology at the basic education level still focuses on two things, namely the impact of its use and utilization in the learning process [3]. The first focus on the impact of using information technology on children focuses more on the positive and negative impacts of the use of information technology on children. One study states that the use of information technology in elementary school children without restrictions will have a negative impact on their emotional and social development [4]. This, at the same time triggers the growth of problematic and unfavorable behavior in children. Second, focus on the use of information technology in the learning process and the implementation of information technology-based learning in schools. Other research focuses on the use of computers for the development of the learning process in science, mathematics, language and arts subjects [5]. 
Journal UMGESHIC

Commenting on the research above, it is true that information technology is neutral, it can have a negative impact as well as a positive impact, it really depends on the management of its use [6]. If information technology is used in a planned manner and with good assistance, the results will be good, but if the use of information technology is carried out carelessly, without planning and supervision, the results will be bad. Another research is research that focuses on the use of information technology (computers) in the learning process of science, mathematics, language, and art, so the research studies will be more complete when information technology is also used in moral and religious learning. Not many studies have focused on the use of information technology in moral and religious development, even though this research is an important part of the educational process [7].

So far, the use of information technology, especially in schools, is more often used by teachers as a medium and learning resource. Preset teachers using computers, LCDs, with power point applications (PPt) are examples of the use of information technology as learning media [8], while teachers looking for teaching materials from the internet are examples of information technology as learning resources. Not many schools have used information technology as a means of learning moral and religious values, but at SD Muhammadiyah Manyar Gresik information technology has been used for this purpose since the beginning.

An overview of the use of information technology in religious learning at SD Muhammadiyah Manyar is prayer learning. Within 1 month $92 \%$ of students were able to memorize the prayer readings and perform the prayer movements perfectly. Departing from this phenomenon I intend to conduct research on this matter, the results of this study are expected to be used as a reference for other Muhammadiyah schools to optimize information technology in learning. The use of information technology in learning is certainly a good innovation that is very helpful for teachers and students. Especially after the 2013 curriculum was implemented, the teachers became very busy because of the complicated task of planning and evaluating learning. Through information technology, teachers will be greatly helped because some of their duties and functions can be replaced.

\section{Literature review}

\subsection{Learning Innovations}

Innovative learning is learning that develops the potential of students with various activities oriented towards student centered learning (SCL), outcome based learning, and constructivism [9]. In addition, innovative learning is learning that is oriented towards increasing student participation through student centered [10]. In addition, innovative learning is learning that organizes content and teaching activities so that innovative activities occur. There are several examples of innovative learning including contextual teaching and learning, cooperative learning, mastery learning, problem based learning, project based learning, and project based learning. computer-based (computer assisted learning) [11]. Contextual teaching and learning is learning that relates material to the real world. This learning will motivate students to make connections between knowledge in life. Second, cooperative learning (cooperative learning) is learning designed to share the responsibilities of students in learning. This learning also emphasizes teamwork although it does not neglect individual responsibility. Complete learning (mastery learning) is learning that is directed so that students are able to master basic competencies (basic learning objectives) completely. The principle of this learning is that every student is able to complete basic competencies if given sufficient time. If the learning time is not enough, the consequence is the incomplete competence of students [12].

Third, problem-based learning (problem based learning), namely learning that uses problems as the basis for student learning materials. Through this learning, students will practice critical thinking to solve various problems posed to them. This learning is often referred to as project-based learning because the learning steps are the same. Problem-based learning steps are formulating problems, collecting data, and analyzing data. The emphasis of both is the same, namely the existence of an active student environment, teamwork, and authentic evaluation techniques. Computer-based learning (computer assisted learning) is learning in which students interact with computers. This learning emphasizes the occurrence of interactive behavior between students and computers. 


\subsection{Information Technology}

In everyday life, without realizing it, the findings of science and technology have accompanied human life, one of which is information technology. Information technology has long been used in human life, including in education. Information technology is a means of infrastructure that provides information services for the convenience of human life [13]. Information technology devices such as televisions, computers, internet, cell phones, or others are the infrastructure that provides the service. This device processes various information and distributes it in digital form. Information technology devices are an important part of modern society and their existence cannot be separated from all aspects of life including education [14] [15].

There is a tendency that the future of Indonesian education is open, meaning that education can be done using technology that can be done remotely. This trend makes communication technology-based services very important. The second trend is the increasing use of information technology in learning, including the internet [6].

This phenomenon encourages schools to optimize the use of information technology in planning, implementing, and evaluating learning. Information technology is currently not only a supporting tool but also the main means of supporting the success of education. There are three main forces in the 21st century, namely science, technology, and information, all of which play an important role in human life and schools are obliged to facilitate it [16].

There are several advantages when teachers use information technology in learning. This advantage is not only obtained by teachers, but also students. First, the time in the learning process will be shorter, this is because students complete their work faster [17]. In essence, teachers who use information technology in learning will take shorter time than teachers who do not use it [5]. Second, by utilizing information technology teachers will focus more on discussion activities and student answers [18].

There are still many benefits that will be obtained by teachers and students if they take advantage of information technology in learning, such as increased student interaction with their peers [19], students can work together in groups so as to improve communication between students. Information technology can also increase students' attention to the learning process because of the existence of interesting learning resources (Higgins et al. (2005), this happens because information technology can provide interesting learning resources, namely providing images, animation, text, and even videos.

\section{Method}

This type of research is a descriptive study that will investigate in depth about moral and religious learning innovations through information technology at SD Muhammadiyah Manyar. The research focus is on learning planning, learning process, and learning evaluation. The research subjects were the principal, vice principal in the field of curriculum, teachers, and the moral and religious learning process in schools. The research design is as follows: research planning $\rightarrow$ research implementation $\rightarrow$ research data analysis $\rightarrow$ drawing conclusions $\rightarrow$ making reports.

Before carrying out research, the researcher finalizes the research design by determining several things; a) formulation of research problems, b) review library materials, c) determine research subjects, and d) prepare research instruments. Furthermore, the researcher goes into the field of research to collect data by making observations and interviews, as well as collecting documents of the learning process, and trying to find important variables in the research. Researchers will conduct interviews with school principals, vice principals in the field of curriculum, and teachers to gather information about moral and religious learning innovations through information technology. Through interviews, researchers hope to get as much information as possible so that the research results can be in-depth. The following is a research data collection instrument.

1. How is the innovation of moral and religious learning through information technology?

2. What are the obstacles in moral and religious learning through information technology?

All further research data will be analyzed and the analysis model used is the Mils and Hubermen model. In this model, there are three steps, namely: (1) data reduction, (2) data presentation, and (3) 
drawing conclusions. In data reduction, the researcher will abstract the rough data from the field to sharpen, classify, direct, and remove unnecessary data. After that the data is presented in the form of descriptions, matrices, relationships between categories, and narrative text form, the aim is to make it easier for researchers to read and draw conclusions. The third step is drawing conclusions. After presenting the data and research evidence, the researcher will draw conclusions. The initial conclusions put forward are actually still provisional, but if no stronger evidence is found then the conclusions are final.

\section{Results and discussion}

Before discussing the results of the research, it is first stated that there are 4 morals or ethics taught in grade 1 at SD Muhammadiyah Manyar. The four ethics are ethics towards parents, ethics towards teachers, ethics towards friends, and ethics when studying. Based on observations it is known that ethics learning makes a lot of use of learning videos. The activity is watching together in class according to a predetermined theme. The devices used are a computer, LCD projector, and a sound system. The teaching materials used are stories or stories related to the above themes downloaded from Youtube. The purpose of watching together is in order to instill the concept of certain desired behavior in students.

For example on Monday, the theme of learning is filial piety to parents, so the video that is presented is the ethics of children to parents. The contents of the video include procedures for respecting parents, encouragement to do good to parents, prohibition of speaking harsh words to parents etc. After watching the teacher invites discussion by giving short questions to students. After that the students recount the contents of the story to their classmates. Thus, at a glance, learning ethics uses learning videos, this is also done for the theme of ethics to teachers, ethics to friends, and ethics when studying. The learning sequence and sequence are the same, namely watching the video, question and answer, and telling stories about the contents of the video.

The learning evaluation technique used is the observation technique, meaning that students are assessed through observations of their daily behavior. To measure the ethics of students towards parents, teachers involve parents as observers. Meanwhile, for the theme of ethics to the teacher, the teacher himself will be the observer. Finally, to measure the ethics of students to friends, their peers are the observers. Thus the first step that the teacher must take is to develop an assessment instrument. Evaluation is carried out within a certain period of time with the intention of ensuring that these ethics have really become the habit of students [20].

The use of learning videos is also carried out to instill the concept of religious faith, such as belief in the existence of Allah, Angels, books, the apostles, the Day of Judgment, and destiny. Based on the teacher's explanation, the use of this video is very helpful for students because it is easier for them to understand because there is a visualization. Students are also very interested in following the learning process because it is not monotonous. Learning videos are also used to improve students' prayer skills such as the practice of ablution and prayer. For ablution skills, there are two competencies that must be mastered by students, namely the truth in the sequence and the correctness of the movement, likewise there are two competencies for prayer skills, namely the truth of the prayer movement and the truth of the reading.

The practice of wudlu and prayer at this school is carried out at two times, namely at Dhuhur and Asr. The teacher plays the video about wudlu when it is nearing dhuhur time, while the video about prayer is played at the same time when the students practice their prayers. The technical implementation is that students do by imitating the movements and prayer readings from the video that is played in front 
of them. The teacher's position is to be the supervisor of the prayer practice to ensure that the movements and readings of the students' prayer are really correct.

The target of learning to pray in this school is not limited to capable and able students, but they are accustomed to praying. Two compulsory prayers, namely Dhuhur and Asr, have been performed at school but Maghrib, Isha 'and Fajr prayers of students do it at home. To ensure that students pray at home, the role of both parents is very important. To bridge this, the school has created a "Ananda Telephone Ringing" program, which is a program for calling students to remind them of prayers at home. The teacher made a call via Vidio Call on the group WA application to remind students to pray at the beginning of time. Each student gets a phone call three times a semester, and after that they also call their group friends in a chain.

Utilization of information technology is also used to train recitation and strengthen recitation of the Qur'an. The target of memorizing Al Qur'an class 1 is 8 short letters in Juz Amma, to achieve this target the teacher uses the murattal recordings of the experts in reading the Qur'an before the learning process. This activity is carried out every morning so that students unconsciously memorize and do memorization murojaah without them knowing it. The same thing is done to memorize selected hadiths.

There are three findings in this study, related to the use of IT in moral and religious learning. The first finding is the use of videos for moral or ethical learning, faith, and worship. The second finding is the use of video calls to create habits of worship for students at home, and the third finding is the use of murattal recordings to practice Al-Quran pronunciation and memorization. The first finding regarding the use of videos for learning is something that is practical, easy, and cheap. Through the world wide web (www) teachers will find it easier to get teaching materials, even search engines (browsers) can find it in various forms such as text, images, sound, and videos [1].

Learning by teachers can also be more effective and faster because they don't have to explain in detail. Simply watching the video represents the message you want to convey. The main reason is the practicality factor, by utilizing IT tools the teacher does not have to bother explaining the material, just press a button so the learning material has been conveyed. The third is the reason for the learning outcomes, by using the video learning outcomes of students are better because the video can explain in more detail and clearly. Another reason is the effectiveness if the teacher uses videos in the learning process, the time for the learning process is shorter because students complete their work more quickly [17]. In essence, teachers who use information technology will need less time than teachers who do not use it.

The second finding is the use of video calls to create a habit of praying for students at home. With video calls, the teacher can monitor and invite students to pray, thus the teacher can learn remotely. Uno (2011) states that the future trend of Indonesian education is open education, meaning that education can be done using technology that can be done remotely. This is to break the habit of students so that they always spell prayer.

As an Islamic school, this school applies indoctrination and habituation in moral and religious learning. The implementation of both is carried out in the form of programs and school culture. Habituation is also carried out especially in certain manners such as adab to parents, courtesy to teachers, adab to friends, and manners when studying etc. In this habituation implementation the teacher uses and makes use of video calls in their learning. So in religious learning there is indoctrination and habituation. This includes the habituation of memorizing Al Qur'an through murattal recordings to train students to memorize the Qur'an. 


\section{Conclusion}

Moral and religious learning innovations at Muhammadiyah Elementary School are carried out through the following: 1) the use of videos for learning morals or ethics, faith, and worship. 2) the use of video calls to create student worship habits at home. 3) the use of murattal recordings by experts reading the Al-Qur'an to train students' pronunciation and memorization of Al-Qur'an. Suggestions for schools to make learning in the classroom more contextual and animated by students, in the future schools need to develop their own videos as teaching materials.

\section{References}

[1] Zukker, "“Application of social cognitive theory to training for computer skills', Information systems research," vol. 6, no. 2, pp. 118-143, 2009.

[2] E. a. D. Glover, "The evolution of an effective pedagogy for teachers using the interactive whiteboard in mathematics and modern languages: an empirical analysis from the secondary sector', Learning, Media and Technology," vol. 32, 2007.

[3] Syahbana, Inovasi Teknologi dalam Pembelajaran. Jakarta: Bumi Aksara, 2014.

[4] Hosokawa, Rikuya., T. Katsura., and Pl. One., "Association between mobile technology use and child adjustment in early elementary school age," vol. 13, no. 7, 2015.

[5] Higgins et al., "Embedding ICT in the literacy and numeracy strategies : final report," 2005, [Online]. Available: http://dro.dur.ac.uk/1899.

[6] H. Uno, Menjadi Guru Profesional Menciptakan Pembelajaran Kreatif dan Menyenangkan. Bandung: Remaja Rosda karya, 2011.

[7] M. et. al. Cox, "ICT and Attainment: A Review of the Research Literature," 2004. .

[8] H. C. et. a. Harton, “Focused Interactive Learning: a tool for active class discussion', Teaching of Psychology," vol. 29, pp. 10-16, 2012.

[9] Ghufran and Anik, Pembelajaran Inovatif. UNY PRESS, 2015.

[10] Naim and Ngainun, Menjadi Guru Inspiratif. Yogyakarta: Pustaka Pelajar, 2015.

[11] J. et. a. Soutchott, "The intersections of curriculum development: Music, ICT and Australian music education,” Australas. J. Educ. Technol., vol. 27, 2011.

[12] Syah and Muhibbin, Psikologi Pendidikan. Bandung: Remaja Rosdakarya, 2014.

[13] Depatemen Pendidikan Nasional, "Kamus Besar Bahasa Indonsia Pusat Bahasa," in Kamus Besar Bahasa Indonsia Pusat Bahasa, San Fransisco, 2014.

[14] Macedo and F, "Teaching creative music technology in higher education: A phenomenological approach. Journal of Music, Technology \& Education," vol. 6, no. 2, pp. 207-219, 2013.

[15] S. Wise, "Teacher and student perceptions of digital technology in secondary school music education: a case study. e-journal of Studies in Music Education," vol. 9, 2010.

[16] Tilaar, Model-Model Pembelajaran Mengembangkan Profesionalisme Guru. Jakarta: PT Raja Grafindo Persada, 2012.

[17] Lee, M, Boyle, and M, "The educational effects and implications of the interactive whiteboard strategy of Richardson primary school," 2003.

[18] B. Ball, "'Teaching and learning mathematics with an interactive whiteboard," vol. 19, pp. 4-7, 2003.

[19] Elaziz and F, "Attitudes of students and teachers towards the use of Interactive whiteboards in EFL classrooms," Bilkent University, Ankara, 2008.

[20] Depatemen Pendidikan Nasional, Undang-Undang Republik Indonesia. No. 20 Tahun 2003 tentang Sistem Pendidikan Nasional (Sisdiknas). 2003. 